\title{
Individual variability in patterns and dynamics of fecal gluten immunogenic peptides excretion after low gluten intake
}

\author{
Laura Coto $^{1,2}$ (D) Carolina Sousa $^{3}$ (D) Angel Cebolla ${ }^{1}$ D
}

Received: 21 September 2021 / Accepted: 30 November 2021 / Published online: 7 January 2022

(c) The Author(s) 2022

\begin{abstract}
Purpose Determination of Gluten Immunogenic Peptides (GIP) in feces is a direct tool for gluten exposure detection. The sensitivity of GIP detection methods for cases of unintentional low gluten intakes is unknown. We studied the interindividual variability in the kinetic of excretion under homogeneously controlled dietary conditions, and the sensitivity of fecal GIP tests after low amounts of punctual gluten ingestions.

Methods Participants $(n=20)$ followed the same gluten-free menu for 12 days in which two separated doses of gluten $(50 \mathrm{mg}$ and $2 \mathrm{~g}$ ) were ingested and all the depositions were collected. GIP from stool samples were analyzed by ELISA and lateral flow immunoassay (LFIA) tests.

Results Most participants had detectable GIP after $50 \mathrm{mg}$ and $2 \mathrm{~g}$ gluten ingestions using ELISA test (72.2\% and 95\%, respectively), whereas the LFIA test showed less sensitivity ( $22.2 \%$ and $80 \%$, respectively). GIP were detected at higher either frequency or concentration in the range of $12-36 \mathrm{~h}$ after $50 \mathrm{mg}$ intake, and $12-84 \mathrm{~h}$ after $2 \mathrm{~g}$ consumption. Considering this period, diagnostic sensitivity of GIP detection after a single $50 \mathrm{mg}$ ingestion may be significatively increased analyzing three stool samples per individual. High variability among participants was found in the time and amount of GIP excretion; however, some individuals showed common patterns for both gluten intakes.

Conclusion Sporadic gluten exposure detection may require several fecal samples to achieve level of sensitivity above $90 \%$. Interindividual variability in the dynamic of GIP excretion may suggest patterns of gluten metabolism.
\end{abstract}

Keywords Gluten immunogenic peptides · Gluten metabolism · Gluten detection feces · Gluten-free diet monitoring · Celiac disease

\section{Introduction}

Celiac disease $(\mathrm{CD})$ is a chronic, multiorgan autoimmune disease that occurs in genetically predisposed individuals with well-known genetic components such as human leukocyte antigen (HLA-DQ2 and HLA-DQ8), an auto-antigen (tissue trans-glutaminase), and gluten [1]. Additional environmental contributors have been suggested to be involved in its development, such as infections, imbalanced intestinal

Angel Cebolla

acebolla@biomedal.com

1 Biomedal S.L., Polígono Industrial Parque Plata, Calle Calzada Romana, 40, 41900 Camas, Sevilla, Spain

2 Human Nutrition and Food Science Doctoral Program, University of Granada, 18011 Granada, Spain

3 Department of Microbiology and Parasitology, Faculty of Pharmacy, University of Seville, 41012 Seville, Spain microbiota, and increased intestinal permeability [1-3]. The pathogenesis of $\mathrm{CD}$ involves the passage of gluten immunogenic peptides (GIP) through the intestinal barrier into the lamina propria via the trans- or paracellular route, with consequent activation of both adaptive and innate immune responses [4-7]. Reportedly, the $\alpha$-gliadin 33 -mer peptide is one of the most dominant immunogenic peptides, which contains three-six different potential T-cell epitopes of CD [8]. Three other gluten peptides are shown to produce most of the immunogenic responses observed in patients with $\mathrm{CD}$ [9].

Gluten is a water-insoluble polymorphic mixture of storage proteins, which are mainly categorized as alcohol-soluble prolamins and the alcohol-insoluble glutelins. Cereal grains such as wheat, rye, and barley contain high quantities of gluten, whereas oats show much lower content [10]. Prolamins impart specific functional properties such as viscoelasticity to food product; therefore, these cereals are used in 
a broad range of foodstuffs [11]. Prolamins are structurally characterized by unique repetitive amino acid sequences, rich in glutamine and proline; therefore, they are not easily digested by gastric and pancreatic enzymes [10].

Dietary gluten proteins are partially hydrolyzed in the stomach over a few minutes to $2-4 \mathrm{~h}$, depending on the diet. Proteolytic degradation primarily occurs in the small intestine as a result of pancreatic enzyme activity, which cleaves polypeptides into small peptides and amino acids that are absorbed by transport systems [12,13]. Previously, it was assumed that only di- or tripeptides are absorbed thorough the intestines; however, studies have shown that longer-chain gluten peptides resistant to digestion can enter the portal circulation, undergo filtration by the kidneys, and get excreted in urine [14]. Undigested gluten proteins and large peptides that remain intact in the small intestine may serve as substrate for local microbiota able to hydrolyze gluten [15]. The residual undigested peptides finally enter the large intestine, which contains a high density of living bacteria, and are further hydrolyzed over at least $10 \mathrm{~h}$ or even several days. The length and the activity of the hydrolytic process are largely dependent on the gut microbiota and the nature of the protein and the food matrix. Food components, including gluten proteins, that are not digested by enzymes and intestinal microbiota undergo fecal elimination [12, 13, 16, 17].

Strict lifelong compliance with a gluten-free diet (GFD) is the only treatment currently available for patients with $\mathrm{CD}$, which implies avoidance of all gluten-containing foods and close attention to cross-contamination [18]. However, complete exclusion of dietary gluten is difficult in real-world practice because of the ubiquitous nature of gluten, social aspects and socioeconomic factors [19-21]. Consequently, GFD compliance in patients with CD was reported to be between 12 and 90\% in adults [22-24] and between 23 and $98 \%$ in children [25], being asymptomatic patients more susceptible to regular gluten ingestion [22, 23]. A recent study reported that frequent gluten consumption showed by excreted GIP was associated with histological lesions, which may lead to future complications as a result of their condition [23].

Currently, a safe threshold of daily gluten intake among those with $\mathrm{CD}$ is unavailable, and the immune response to gluten significantly varies among this patient population [26]. Catassi et al. [27] concluded that the daily ingestion of contaminating gluten should be $<50 \mathrm{mg}$, based on histopathological findings observed in patients who received this dose. Additionally, other authors reported a gluten intake below $30 \mathrm{mg}$ to avoid intestinal mucosal abnormalities [28].

Estimation of fecal and urinary GIP is the most direct method to monitor gluten ingestion [14, 17, 29]. In addition to control the adherence to a GFD, this method may also enable direct and quantitative assessment of gluten exposure, which refers to unintended low gluten intake.
Information about the specific time, amount of ingested gluten and expected sensitivity for occasional gluten exposure may be important to design either the frequency of testing or the protocols to assess GFD compliance in patients with CD. Despite other authors have reported information about the process of GIP elimination in feces $[17,30-32]$, no data are available to date regarding the dynamic of GIP excretion, the influence of individual variability and the sensitivity of the method after punctual gluten exposure maintaining identical daily diet. In this study, we determined fecal GIP excretion collecting samples from all the depositions of participants under a GFD, with two separated ingestions of $50 \mathrm{mg}$ and $2 \mathrm{~g}$ of gluten with minimal dietary variations.

\section{Methods}

\section{Study design and population}

This prospective study included 20 healthy adults recruited between January 2020 and March 2020. The study protocol was reviewed by the ethics committee, and written informed consent was obtained from all participants (n. 2381-N-19). All participants were instructed to exclude gluten-containing food from their habitual diet for one week and to collect a urine and feces sample to confirm adherence to GFD 2 days before the ingestion of the first dose (Fig. 1). After this pretest preparation, participants were provided with equivalent prepared gluten-free ready-to-eat lunch and dinner meals and gluten-free bread, which were supplied daily by the research team. The prepared meals were consumed within the prescribed GFD. Two doses of gluten (50 $\mathrm{mg}$ and $2 \mathrm{~g}$ ) were ingested in the morning (9:00 am) on days 8 and 12, respectively, and one sample each of all the stools and urine (data published separately [33]) passed throughout the day was collected over the duration of the entire study period (12 days).

A food-recall questionnaire was used to determine GFD adherence and fluid intake from the commencement to completion of the study. Participants were instructed to record the name and the quantity of the food items that they consumed daily.

The inclusion criteria for the study were as follows: (1) age $>18$ years, (2) no diagnosis of $\mathrm{CD}$, non-celiac gluten sensitivity, food allergies, food intolerances, and other gastrointestinal diseases, (3) willingness to follow a strict diet and, (4) willingness to collect daily stool samples.

The exclusion criteria were as follows: (1) diagnosis of concomitant pathological conditions or severe psychiatric illnesses and, (2) inappropriately collected samples on at least $70 \%$ of all occasions. 


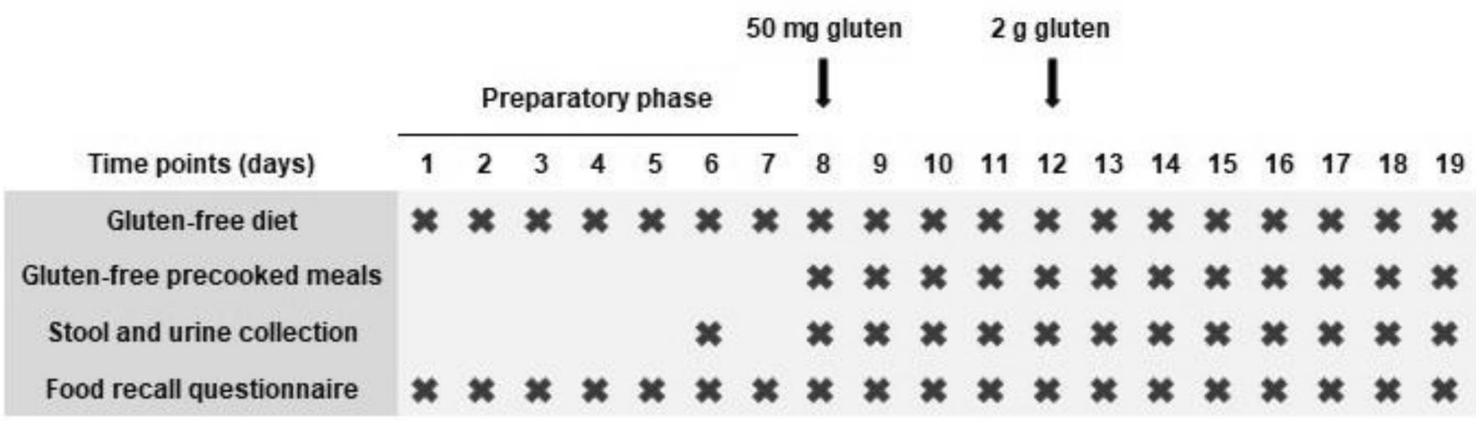

Fig. 1 Study timeline

\section{Gluten doses}

Gluten doses were administrated in the form of gelatin capsules ("000" size, Your Supplements ${ }^{\mathrm{TM}}$, Bredbury, Stockport, England) filled with powdered wheat gluten El Granero Integral $^{\text {TM }}$ (Biogran S.L., Madrid, Spain). Gelatin capsules were analyzed using the GlutenTox ${ }^{\circledR}$ enzyme-linked immunosorbent assay (ELISA) Sandwich kit (Hygiena, Seville, Spain) to confirm the absence of gluten.

The gluten dosage was selected as follows: $50 \mathrm{mg}$, considered as the minimum amount of gluten that can produce histopathological changes, following daily intake in patients with $\mathrm{CD}$ [27], and $2 \mathrm{~g}$, amount considered the dose necessary to evaluate the dynamics of fecal GIP excretion.

We performed specific calculations using a slice of common bread based on the methodology described by Biagi et al. to interpret these gluten quantities in terms of food [34]. The slice of bread measured $11 \mathrm{~cm} \times 12 \mathrm{~cm}$ in size and weighted $30 \mathrm{~g}$. Based on the nutritional composition provided by the manufacturer, the entire slice contained $2.48 \mathrm{~g}$ of gluten. The corresponding amount of bread for $50 \mathrm{mg}$ and $2 \mathrm{~g}$ of gluten were $0.6 \mathrm{~g}$ and $24 \mathrm{~g}$, respectively (Fig. 2). A battery (AAA) was used to show the size of the pieces of bread.

Several samples of maize starch, Maizena ${ }^{\mathrm{TM}}$ (Unilever, London, England) were spiked with the powdered gluten of different concentrations and analyzed using GlutenTox ${ }^{\circledR}$ ELISA Sandwich kit (Hygiena, Seville, Spain) using G12 and $\mathrm{A} 1$ antibodies for gluten estimation. Based on the results obtained (nearly $100 \%$ recovery), gluten doses for each participant were prepared using the total weight of the powdered gluten as follows: $50 \pm 5 \mathrm{mg}$ and $2,000 \pm 5 \mathrm{mg}$ in 1 and 4 capsules, respectively.

\section{Prescribed gluten-free diet}

To reduce variability in the results, all the participants followed the same isocaloric GFD prepared by a registered dietitian. Prepared ready-to-eat meals for lunch and dinner were ordered from a catering company, and all items were analyzed by the ISO17025 certified Biomedal laboratory using the GlutenTox ${ }^{\circledR}$ ELISA Sandwich kit (Hygiena,
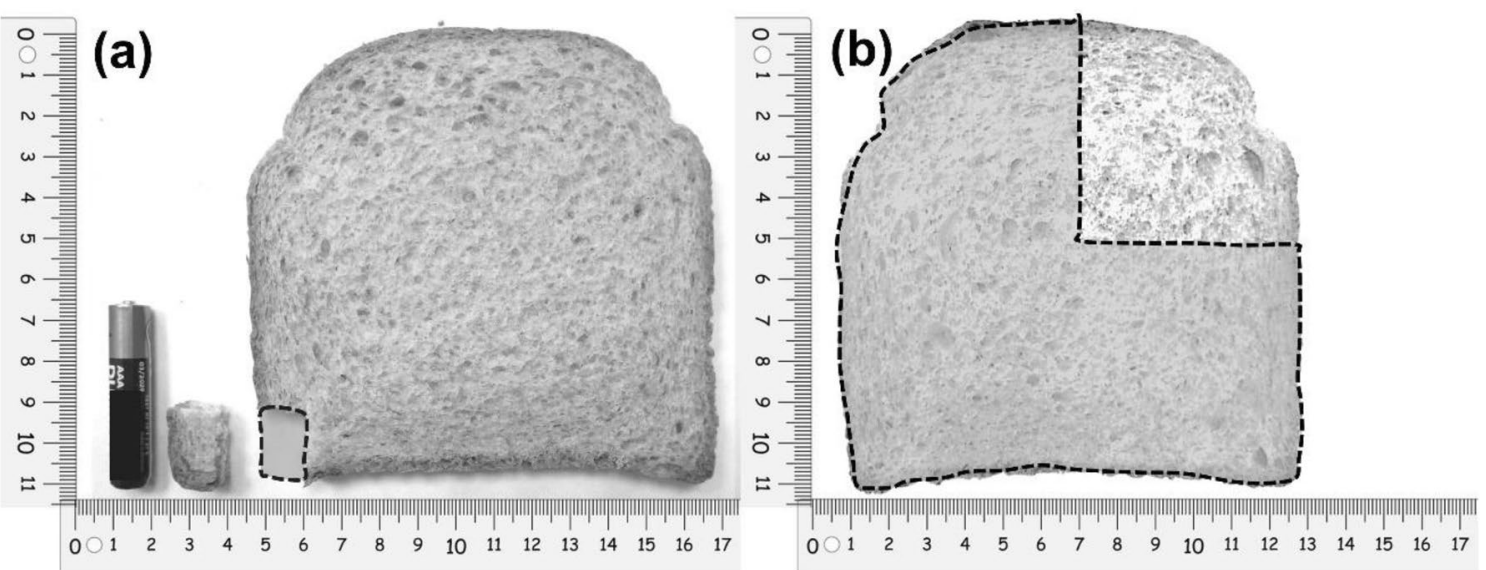

Fig. 2 Representation of gluten doses in a slice of bread. Dashed lines show the portion of the slice which represent $50 \mathrm{mg}$ of gluten (a) and $2 \mathrm{~g}$ of gluten (b). The small piece of bread representing $50 \mathrm{mg}$ of gluten is also compared in size to a AAA battery (a) 
Seville, Spain) to confirm the absence of gluten. Gluten-free certified bread (Beiker ${ }^{\mathrm{TM}}$, Dr. Schär, Postal BZ, Italy) was also provided for breakfast time and to complete the meals. Fresh fruits, unprocessed nuts, and gluten-free beverage ingestion were freely permitted, depending on the energy requirements and dietary habits of each participant.

\section{Stool collection}

Detailed instructions were provided to all the participants at the commencement of the study. Participants were provided with all the material for stool collection, including specific plastic screw-capped containers, labels, cool bags, isothermal boxes, and cool packs and were instructed to collect a minimum of $10 \mathrm{~g}$ of stool each time and to record the date and time of collection. All stool samples were preserved in isothermal boxes with cool packs at $4-8{ }^{\circ} \mathrm{C}$ and were submitted to the laboratory within $48 \mathrm{~h}$ of collection. All samples were stored at $-20^{\circ} \mathrm{C}$ until they were processed.

\section{Stool analysis}

Qualitative analysis of GIP in stool samples was performed using a lateral flow immunosorbent assay (LFIA) using the iVYCHECK GIP Stool kit (Biomedal S.L., Seville, Spain) based on the manufacturer's guidelines. Stool samples were extracted with an ethanol-water extraction solution and shaken vigorously intermittently for $10 \mathrm{~min}$. Ten drops of the extracted sample were transferred to a tube containing a dilution solution and thoroughly mixed by inverting the tube for $15 \mathrm{~s}$. Thereafter, eight drops of the mixture were placed in the immunochromatographic cassette, and the results were visually interpreted after $30 \mathrm{~min}$. (recommended time for samples containing a low amount of GIP). A red color at the test line and green color at the control line was interpreted as a positive result, and a green color at the control line was interpreted as a negative result. Each stool sample was tested in duplicate.

The concentration of GIP in stool samples was also measured using a sandwich ELISA technique with the iVYLISA GIP Stool kit (Biomedal S.L., Seville, Spain) based on manufacturer's guidelines. Stool samples were incubated for $60 \mathrm{~min}$ at $50{ }^{\circ} \mathrm{C}$ in $5 \mathrm{~mL}$ ethanol-water extraction solution per $\mathrm{mg}$ of stool with gentle agitation to release the GIP from the stool matrix. After extraction, samples were diluted 1:10 and incubated for $60 \mathrm{~min}$ in the microtiter plate coated with G12 together with the standards and assay controls. The wells were subsequently washed, and the samples were incubated with horseradish peroxidase conjugated G12 antibody for the next $60 \mathrm{~min}$. The plates were washed again and incubated with the horseradish peroxidase substrate. Sulfuric acid was added to prevent color development, and absorbance was measured at $450 \mathrm{~nm}$ using a micro-plate reader, the FLUOstar® Omega (BMG Labtech, Ortenberg, Germany) device. The range of measurement using this method was: $0.078-1.25 \mu \mathrm{g} \mathrm{GIP} / \mathrm{g}$ feces. The results were expressed as $\mu \mathrm{g}$ of GIP per $\mathrm{g}$ feces. Each sample was run in duplicate, and at least two different aliquots of each sample were tested.

\section{Statistics analysis}

The calculation of the sample size considered the variability found in GIP excretion between individuals under similar conditions from a pilot study performed previously at Biomedal S.L. Considering that both urine and stool GIP detection methods were studied, the most unfavorable situation was selected. The minimum expected difference was the limit of quantification (0.078), and the dropout rate was 0.2 . With an alpha risk of $5 \%$, a beta risk of $20 \%$ ( $80 \%$ of statistical power) and a standard deviation of 0.101 the sample size needed was 17 subjects. The calculation was made using the tool GRANMO v7.12 April 2012 (Institut Municipal d'Investigació Mèdica, Barcelona, Spain).

Quantitative variables were expressed as the mean (SD) and median (interquartile [IQR] range) and categorical variables as absolute $(\mathrm{N})$ and relative $(\%)$ frequencies. The goodness-of-fit test for normality was performed using the Shapiro-Wilk test.

The Wilcoxon test was used for paired quantitative variables. Cohen's kappa index ( $\kappa)$ was used to measure the degree of concordance between the evaluated investigated diagnostic techniques that showed dichotomous results, and the Landis and Koch criteria [35] were used for the interpretation of the strength of concordance.

A time range for evaluation of GIP excretion dynamic was established at intervals of $24 \mathrm{~h}$, except for the first interval, which was between 0 and 12 hours for better understanding of the results. All samples from each participant within each time range were clustered to obtain a single result per participant. A GIP-positive result in any of the analyzed samples was considered a positive result.

Basic probability rules were used to determine the analytical sensitivity of the investigated techniques over a predetermined time range using different samples collected for the study.

All statistical analyses and graphics were performed using IBM SPSS Statistics 25.0 for Windows (IBM Corp, Armonk, NY, United States), Epidat package, version 4.2 (Consellería de Sanidade, Xunta de Galicia, Spain, Organización Panamericana de la salud [OPS-OMS], Universidad CES, Colombia) and Graphpad Prism 9.0.2 (GraphPad Software, San Diego, CA, United States). A $P$ value $<0.05$ was considered statistically significant. 


\section{Results}

\section{Subjects and samples}

We selected 30 participants for the study between January and March of 2020. Among these, 10 withdrew from the study owing to unforeseen events $(n=6)$ and COVID-19 mobility restrictions $(n=4)$. Therefore, 20 participants, including $13(65 \%)$ females and 7 (35\%) males with a median age of 30.5 years (IQR 24.7-34 years), completed the study (Fig. 3). The study was developed in two rounds (February and March), which included 11 and 9 participants, respectively. No participants were diagnosed with a relevant disease or reported a history of probiotics/fiber supplements intake. Only one participant reported following a special fitness diet before the study.

Based on the food-recall questionnaire, all participants were compliant with the prescribed GFD and the gluten dose ingestion. The mean fluid intake per participant during the study period was $1.5 \pm 0.6 \mathrm{~L} /$ day. The initial questionnaire that provided an overview of participants' habits was completed by $18 / 20$ (90\%) participants. The daily meal frequency was 3 meals/day among $8 / 18$ (44.4\%) participants and 4-6 meals/day among 10/18 (55.6\%) participants; lunch was the main meal of the day for all the participants. Intake of fiber-rich food varied among participants as follows: $12 / 18(66.7 \%)$ participants usually had whole meal bread daily, 12/18 (66.7\%) participants had $\geq 3$ portions of nuts/week, 10/18 (55.6\%) had $\geq 2$ portions of

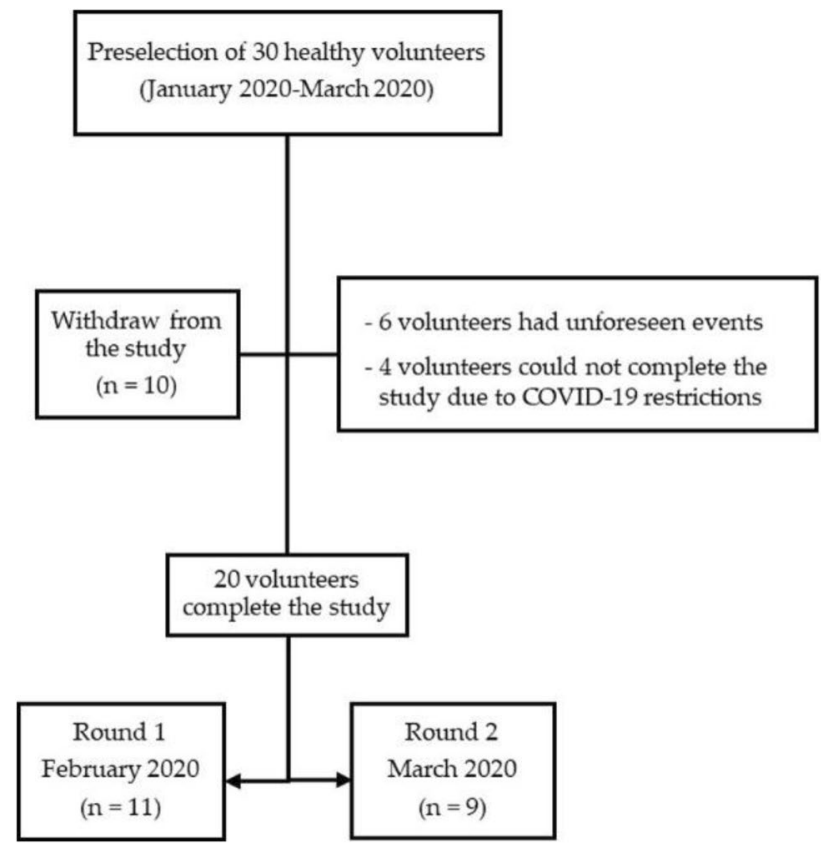

Fig. 3 Flowchart showing distribution of the study participants pulses/week, $3 / 18(16.7 \%)$ had $<3$ portions/day, $12 / 18$ (66.7\%) had 3-4 portions/day and 3/18 (16.7\%) had $>5$ portions of fruits and vegetables/day. Notably, 19/20 (95\%) participants participated in regular physical activity; $8 / 19$ (42.1\%) in low-intensity, and 11/19 (57.9\%) in moderateto-high intensity physical activity.

\section{Dynamics of fecal gluten immunogenic peptide excretion}

A total of 330 fecal samples were collected from all participants; 20 from participants who confirmed GFD adherence prior to gluten ingestion, 92 corresponding to the excretion of $50 \mathrm{mg}$ of gluten and 197 to the excretion of $2 \mathrm{~g}$ of gluten. The remaining 21 samples were excluded from the statistical analysis because GIP-positive results were obtained from the previous gluten-containing diet before study commencement. The median number of samples collected per participant was 16 (IQR 12.3-22.5), and the median stool collection frequency was 1 sample/day (IQR 1-1.5).

Stools samples analyzed over 4 days following $50 \mathrm{mg}$ gluten intake showed GIP in 22/92 (23.9\%) samples based on ELISA testing and in $8(8.7 \%)$ samples based on LFIA testing, corresponding at least one of them to $13 / 18$ (72.2\%) participants and 4/18 (22.2\%) participants, respectively. All samples from two participants were excluded for the $50 \mathrm{mg}$ dose, because they showed GIP-positive results before the gluten intake. Stool samples analyzed over 8 days following $2 \mathrm{~g}$ gluten intake showed GIP in $83 / 197(42.1 \%)$ samples based on ELISA testing and in $42(21.3 \%)$ samples based on LFIA testing. At least one of the fecal samples was positive for $19 / 20$ (95\%) of participants by ELISA and 16/20 (80\%) participants by LFIA, respectively (Table 1). Statistically significant differences were observed between gluten dosages regarding GIP-positive results obtained using ELISA and LFIA techniques ( $P=0.007$ and $P=0.003$, respectively).

GIP corresponding to the $50 \mathrm{mg}$ dose were detected in only one sample in 8/18 participants (44.4\%), in two samples in 3/18 participants (16.7\%), and in four samples in two participants (11.1\%). At the 2 g gluten dose, GIP-positive results were obtained in 1-3 samples in 8/19 participants (42.1\%), 4-6 samples in 6/19 participants (31.6\%), and 8-9 samples in 5/19 participants (26.3\%) (Table 1). Most GIPpositive stools were obtained in the first and second samples collected after the ingestion of $50 \mathrm{mg}$ of gluten by ELISA (6/18 [33.3\%] and 5/17 [29.4\%], respectively) and using LFIA test (2/18 [11.1\%] and 2/17 [11.8\%], respectively). However, among in the $2 \mathrm{~g}$ gluten dose, GIP-positive results were detected in the third and fourth samples collected after gluten ingestion by ELISA (12/20 [60\%] and 13/20 [65\%], 


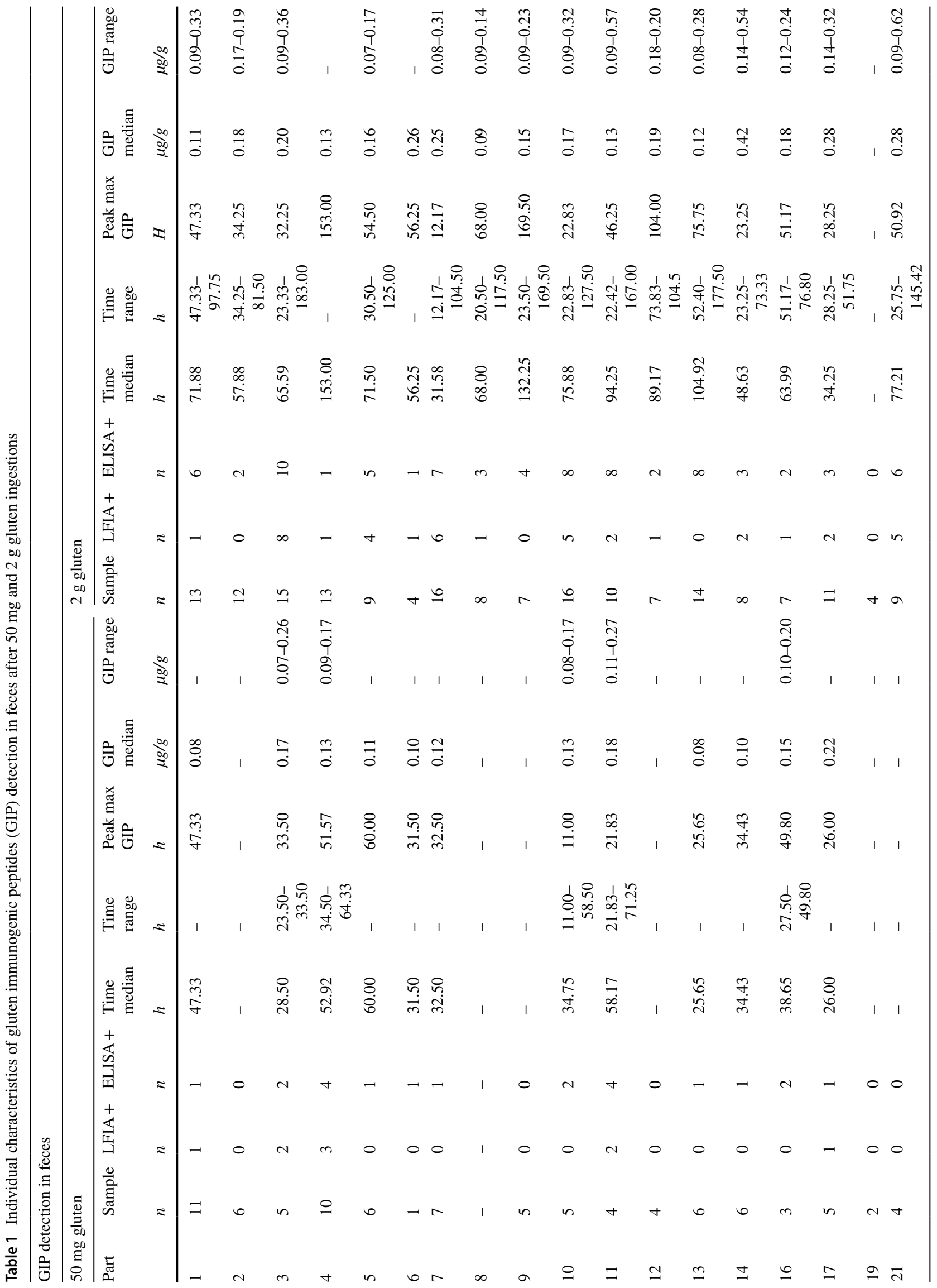


respectively) and using the LFIA test (10/20 [50\%] and 6/20 [30\%], respectively).

\section{Time course of gluten immunogenic peptide excretion}

About GIP excretion over time, most GIP-positive stools after the $50 \mathrm{mg}$ gluten intake were detected between 12 and $36 \mathrm{~h}$ (ELISA [10/18, 55.6\%] and LFIA [4/18, 22.2\%] methods) (Figs. 4, 5). The $2 \mathrm{~g}$ dose showed similar percentages of GIP-positive stools for a longer period (12-84 $\mathrm{h}$ [ELISA] vs. $12-60 \mathrm{~h}$ [LFIA]) with rates ranging from $66.7-72.2 \%$ and 58.6-61.1\%, respectively, expanding the maximum time for detection of GIP-positive stool from $72 \mathrm{~h}(50 \mathrm{mg})$ to $183 \mathrm{~h}$ (2 g) (Figs. 6, 7). In most participants, we observed that GIP was detected in stool samples only after a minimum duration of $20 \mathrm{~h}$ after gluten intake for both gluten dosages. However, GIP were detected in one participant $11 \mathrm{~h}$ post ingestion (50 $\mathrm{mg}$ dose) and in another participant after $12 \mathrm{~h}$ ( $2 \mathrm{~g}$ dose).

Despite significant individual variability, intake of both quantities of gluten was associated with similar median times for initial GIP detection (27.50 h [IQR 23.41-34.47]) for the $50 \mathrm{mg}$ dose and $28.25 \mathrm{~h}$ [IQR 23.25-51.17] for the $2 \mathrm{~g}$ dose), and we observed not significant differences between doses $(P=0.239)$. Among the participants with GIP-positive results following ingestion of both gluten doses, 5/13 (38.5\%) showed similar times regarding initial GIP detection and 8/13 (61.5\%) showed differences in the first sample; 7 with differences ranging from 11-29 $\mathrm{h}$ and one participant with a difference $118 \mathrm{~h}$ in the initial sample. However, the same subject also showed discordant results regarding overall GIP detection; GIP were detected in four samples for the $50 \mathrm{mg}$ dose and in only one sample for the $2 \mathrm{~g}$ dose.

The time range for GIP excretion differed significantly between both gluten doses, as expected; the duration was longer for the $2 \mathrm{~g}$ dose ( $0 \mathrm{~h}$ [IQR $0-26.06$ ] vs. $68.55 \mathrm{~h}$ [IQR 25.63-104.67], $P=0.008)$. The median time for GIP detection was $34.50 \mathrm{~h}$ (IQR.25.91-55.25) for the $50 \mathrm{mg}$ dose and $71.88 \mathrm{~h}$ (IQR 56.25-89.27) for the $2 \mathrm{~g}$ dose, and this difference between doses was statistically significant $(P=0.002)$. Most stool samples collected $72 \mathrm{~h}$ after ingestion of the $50 \mathrm{mg}$ dose showed a GIP-negative result (last detection $71.25 \mathrm{~h}$, corresponding to 3 days), whereas ingestion of the $2 \mathrm{~g}$ dose showed GIP-positive results until the end of the study (GIP were detectable 7 days after ingestion of $2 \mathrm{~g}$ gluten).

\section{Concentrations of gluten immunogenic peptides in stools}

Regarding GIP concentration measured by ELISA, the median among volunteers over 4 days after $50 \mathrm{mg}$ ingestion was $0.02 \mu \mathrm{g} \mathrm{GIP/g}$ feces (IQR 0-0.06), whereas the median over 8 days after the $2 \mathrm{~g}$ intake was $0.07 \mu \mathrm{g} \mathrm{GIP} / \mathrm{g}$ 
Fig. 4 Qualitative results of fecal gluten immunogenic peptides (GIP) excretion after $50 \mathrm{mg}$ of gluten intake using the ELISA. The trend of the GIP detection dynamics is represented by the dashed line
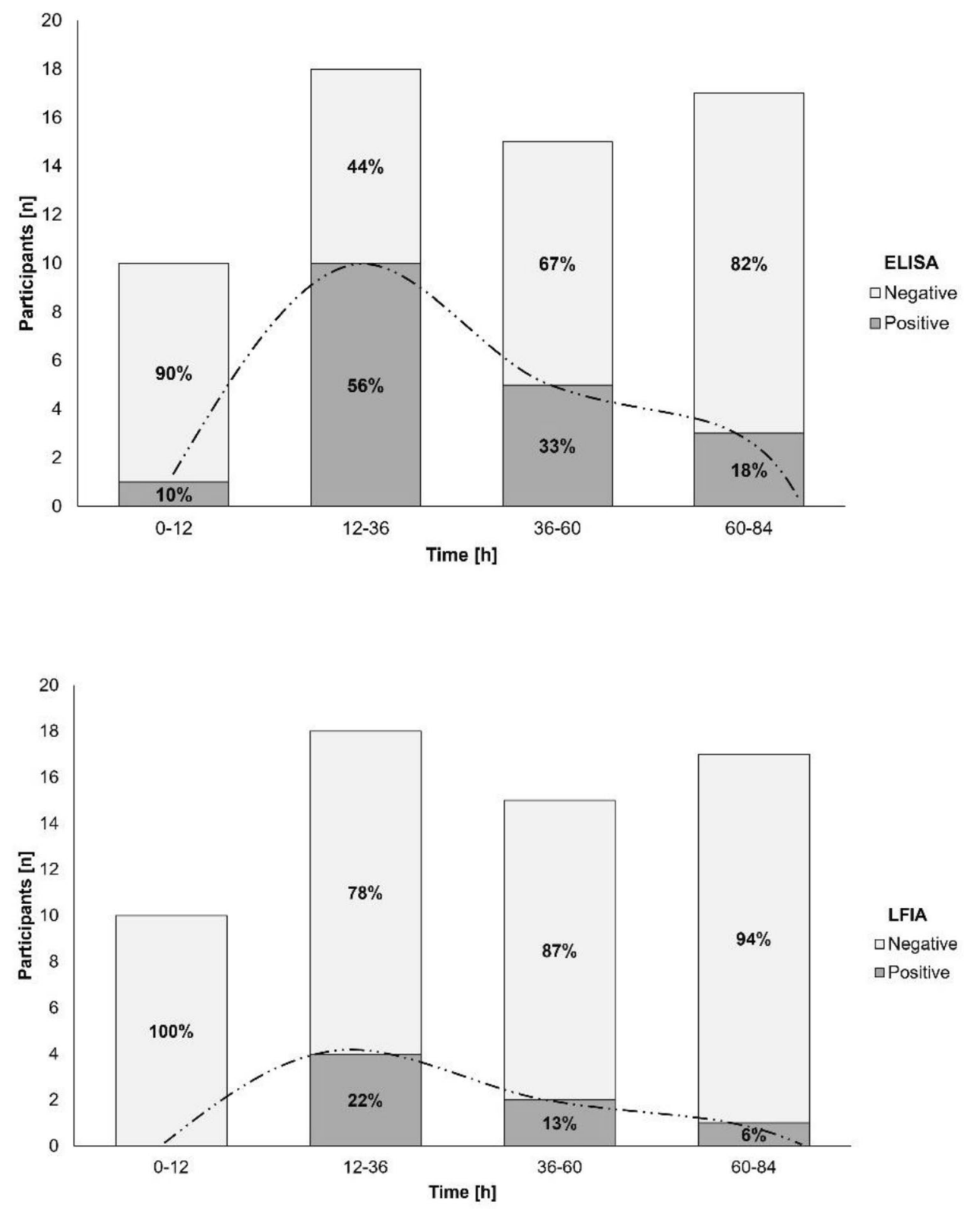

Fig.5 Qualitative results of fecal gluten immunogenic peptides (GIP) excretion after $50 \mathrm{mg}$ of gluten intake using the lateral flow immunoassay. The trend of the GIP detection dynamics is represented by the dashed line feces (IQR 0.05-0.1). Considering only those samples with a GIP-positive result the medians were $0.11 \mu \mathrm{g}$ GIP/g feces (IQR 0.10-0.18) and $0.16 \mu \mathrm{g}$ GIP/g feces (IQR 0.10-0.27), respectively, with significant differences between doses $(P=0.013)$.

GIP concentrations measured by ELISA were higher during the same periods, in concordance with the time required for GIP detection. The median GIP concentration in stools decreased to 0 after $36 \mathrm{~h}$ of ingestion of the $50 \mathrm{mg}$ dose (Fig. 8, Table 2) and after $84 \mathrm{~h}$ of the $2 \mathrm{~g}$ dose (Fig. 9, Table 3).

Considering the range of $12-84 \mathrm{~h}$ after gluten ingestion, the median of GIP concentration for the dose of $50 \mathrm{mg}$ was $0 \mu \mathrm{g} \mathrm{GIP} / \mathrm{g}$ feces (IQR $0-0.08$ ) and for the dose of $2 \mathrm{~g} 0.14 \mu \mathrm{g} \mathrm{GIP/g}$ feces (IQR 0-0.27), with statistically significant differences between doses $(P<0.001)$ (Fig. 10).

\section{Individual variations in patterns of gluten immunogenic peptide excretion}

Overall, we observed high interindividual variability in fecal GIP excretion with varied patterns of GIP excretion (Fig. 11), however, 9/13 subjects showed similarities in excretion patterns with both doses of gluten (Table 1). Some subjects showed peak fecal GIP concentrations within the first $48 \mathrm{~h}$ after ingestion with reduced gluten elimination in the consecutive samples over the study 
Fig.6 Qualitative results of fecal gluten immunogenic peptides (GIP) excretion after $2 \mathrm{~g}$ of gluten intake using the ELISA. The trend of the GIP detection dynamics is represented by the dashed line
25

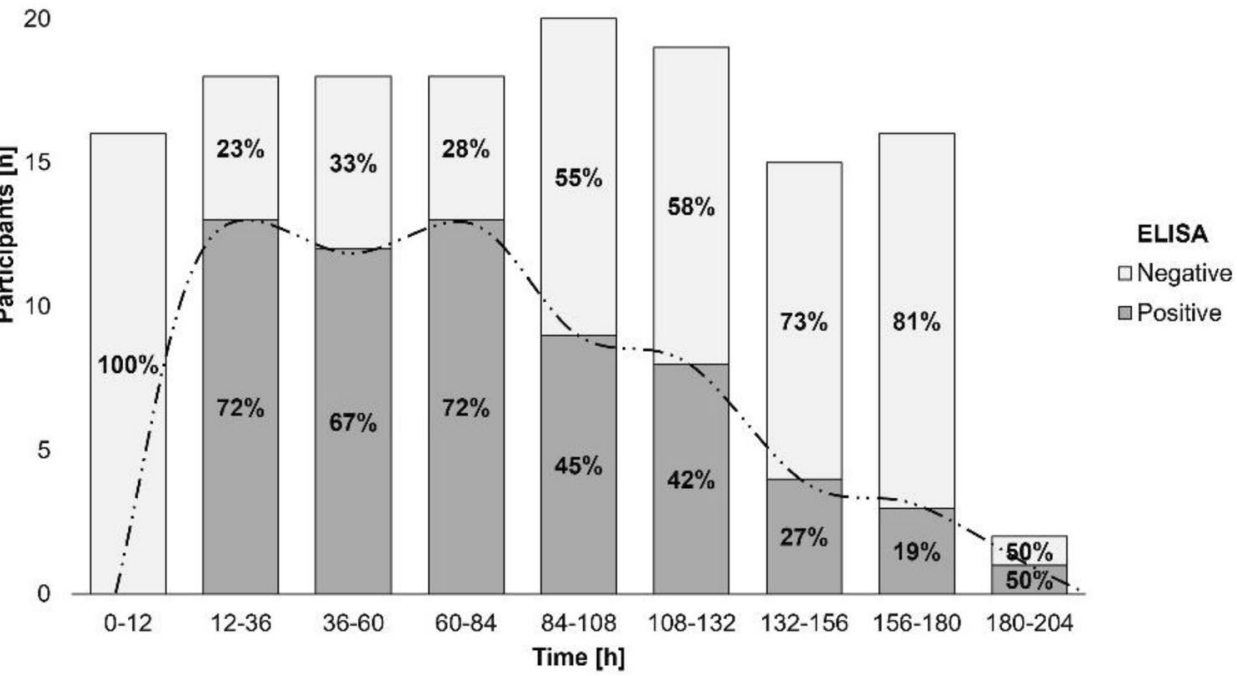

25

Fig. 7 Qualitative results of fecal gluten immunogenic peptides (GIP) excretion after $2 \mathrm{~g}$ of gluten intake using the lateral flow immunoassay. The trend of the GIP detection dynamics is represented by the dashed line

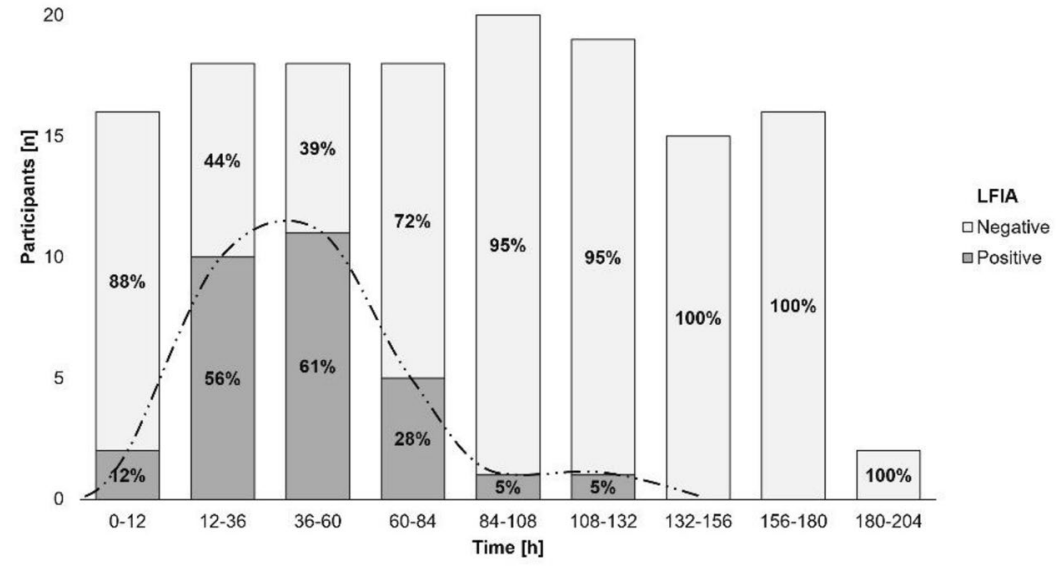

period (Fig. 11a, b). Six of these participants showed a similar pattern with both $50 \mathrm{mg}$ and $2 \mathrm{~g}$ gluten intakes but three of them showed higher GIP concentrations after the $2 \mathrm{~g}$ dose. Furthermore, other participants showed peak GIP concentration after $48 \mathrm{~h}$, three of these with similar times for both gluten ingestions and with discordant results observed in one subject (Fig. 11c, d). Interestingly, two different participants showed an increase in the fecal GIP concentration at the end of the study, but only after ingestion of $2 \mathrm{~g}$ of gluten (Fig. 11e). Additionally, GIP concentrations over and under the limit of detection were observed in many participants during the study period (Fig. 11b, d, e).
When the results were compared between sex, higher GIP concentrations were seen in the group of males in $2 \mathrm{~g}$ gluten intake; however, no statistical significance was observed between females and males in GIP detection $(0.14 \mu \mathrm{g} / \mathrm{g}$ vs. $0.12 \mu \mathrm{g} / \mathrm{g}$, respectively, for the $50 \mathrm{mg}$ dose $(P=0.734) ; 0.17 \mu \mathrm{g} / \mathrm{g}$ vs. $0.29 \mu \mathrm{g} / \mathrm{g}$, respectively, for the $2 \mathrm{~g}$ dose $(P=0.173))$. Furthermore, when $50 \mathrm{mg}$ of gluten where ingested similar results were found between females and males in terms of initial time of GIP detection $((30.88 \mathrm{~h}$ vs. $30.09 \mathrm{~h}$, respectively, $(P=0.866))$ and final time of GIP detection (46.79 h vs. $30.09 \mathrm{~h}$, respectively, $(P=0.176))$. Despite females showed a larger time for initial and final GIP detection than males in the $2 \mathrm{~g}$ gluten intake, no statistically significant differences were 
Fig. 8 ELISA showing dynamics of fecal gluten immunogenic peptides (GIP) excretion following ingestion of $50 \mathrm{mg}$ of gluten. Potential outliers are represented as dots

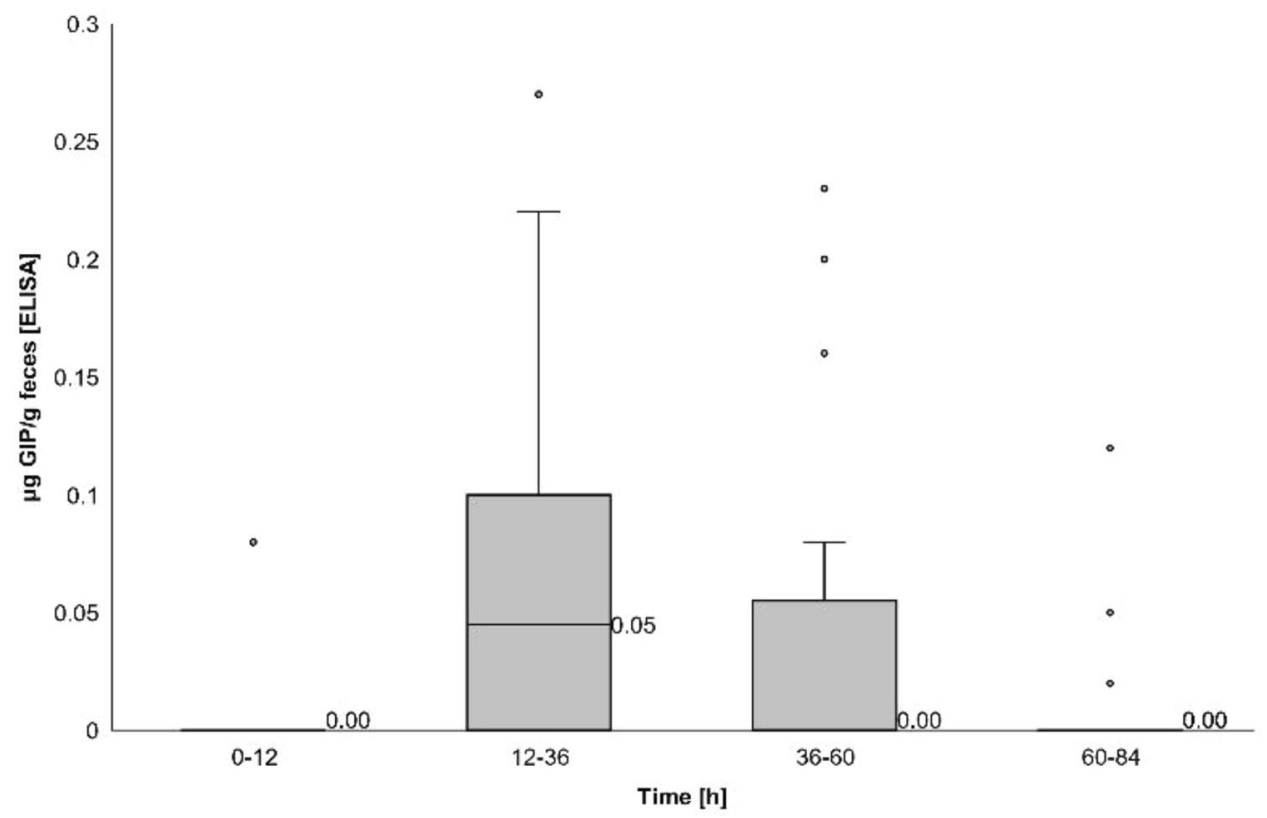

Table 2 Fecal gluten immunogenic peptides (GIP) detection by ELISA in 12-h and 24-h periods after $50 \mathrm{mg}$ gluten ingestion

\begin{tabular}{|c|c|c|c|}
\hline Time & Participants & $\begin{array}{l}\text { GIP + partici- } \\
\text { pants }\end{array}$ & GIP $[\mu \mathrm{g} / \mathrm{g}]$ \\
\hline $\mathrm{h}$ & $\mathrm{n}$ & $\mathrm{n}$ & Median (IQR) \\
\hline $0-12$ & 10 & 1 & $0.00(0)$ \\
\hline $12-36$ & 18 & 10 & $0.05(0-0.10)$ \\
\hline $36-60$ & 15 & 5 & $0.00(0-0.06)$ \\
\hline $60-84$ & 17 & 3 & $0.00(0)$ \\
\hline
\end{tabular}

GIP gluten immunogenic peptides found (48.75 h vs. $20.39 \mathrm{~h}$, respectively $(P=0.136)$ for initial GIP detection and $116.01 \mathrm{~h}$ vs. $67.86 \mathrm{~h}$, respectively $(P=0.380)$ for final GIP detection).

\section{Diagnostic sensitivity of analytical methods}

GIP detection capacity was higher even for a smaller gluten dose with the ELISA than with the LFIA test. Fecal GIP were detected in at least one sample in 13/18 (72.2\%) participants after $50 \mathrm{mg}$ gluten intake within a time interval of 12-84 h, and this rate increased to $18 / 20$ (90\%) following intake of $2 \mathrm{~g}$ of gluten. In contrast, the LFIA method was less sensitive and detected GIP in 4/18 (22.2\%) subjects after $50 \mathrm{mg}$ gluten ingestion and in 15/20 (75\%) subjects after $2 \mathrm{~g}$ gluten ingestion during the same period (12-84 h).
Fig. 9 ELISA showing dynamics of fecal gluten immunogenic peptides (GIP) excretion following ingestion of $2 \mathrm{~g}$ of gluten. Potential outliers are represented as dots

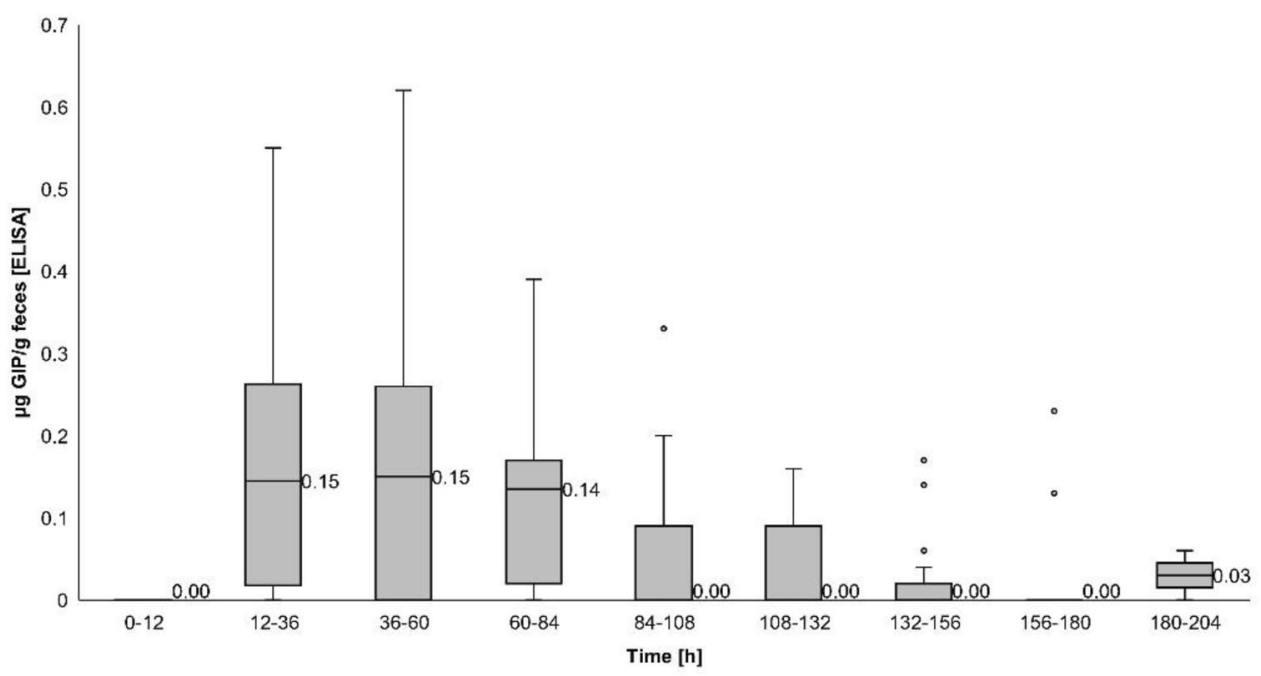


Table 3 Fecal gluten immunogenic peptides detection by ELISA in 12-h and 24-h periods after $2 \mathrm{~g}$ gluten ingestion

\begin{tabular}{|c|c|c|c|}
\hline Time & Participants & $\begin{array}{l}\text { GIP + partici- } \\
\text { pants }\end{array}$ & GIP $[\mu \mathrm{g} / \mathrm{g}]$ \\
\hline $\mathrm{h}$ & $\mathrm{n}$ & $\mathrm{n}$ & Median (IQR) \\
\hline $0-12$ & 16 & 0 & $0.00(0)$ \\
\hline $12-36$ & 18 & 13 & $0.15(0-0.27)$ \\
\hline $36-60$ & 18 & 12 & $0.15(0-0.26)$ \\
\hline $60-84$ & 18 & 13 & $0.14(0-0.18)$ \\
\hline 84-108 & 20 & 9 & $0.00(0-0.09)$ \\
\hline $108-132$ & 19 & 8 & $0.00(0-0.09)$ \\
\hline $132-156$ & 15 & 4 & $0.00(0-0-02)$ \\
\hline $156-180$ & 16 & 3 & $0.00(0)$ \\
\hline $180-204$ & 2 & 1 & $0.03(0-0-06)$ \\
\hline
\end{tabular}

GIP gluten immunogenic peptides

Most of GIP-positive samples detected using LFIA also showed positive results using the ELISA method, but we observed discordant results between methods in six samples even after analysis of three aliquots with ELISA and two aliquots with LFIA. However, due to the methods have different sample extraction protocols any aliquot was analyzed with both tests. In all discordant cases the intensity of the test line was very light, which indicates that the GIP concentration of the sample was close to the limit of detection. Moreover, most GIP-negative results based on LFIA testing (which were positive using ELISA) were in the range of 0.08-0.15 $\mu \mathrm{g} \mathrm{GIP/g}$ feces, concentrations below the limit of detection of the LFIA test. Based on these data, comparison between both methods revealed slight concordance about the $50 \mathrm{mg}$ dose (Cohen kappa $0.35,95 \%$ confidence interval [CI] 0.14-0.56, $P<0.001$ ), which high to moderate concordance in the $2 \mathrm{~g}$ dose, following comparison of all results obtained from both methods (Cohen kappa 0.43, 95\% CI 0.31-0.55, $\mathrm{P}<0.001$; Cohen kappa 0.42; 95\% CI 0.32-0.53, $\mathrm{P}<0.001$, respectively).

Considering $12-84 \mathrm{~h}$ after gluten intake as the interval of time suited for GIP detection using both techniques, we calculated the theoretical probability of at least one GIP-positive stool sample after a single gluten ingestion (Table 4). The diagnostic sensitivity of the ELISA test for detection of GIP in a sample after digestion of a small amount of gluten (50 mg) was $27.3 \%$, which increased to $47.1 \%$ in two and to $61.5 \%$ in three samples. Although the LFIA test showed a lower sensitivity for the same quantity of gluten intake in one sample (10.4\%), the probability reached $19.7 \%$ in two and $28 \%$ in three samples.

We observed that the sensitivity of a single sample could be as high as $67.5 \%$ using ELISA, and $46.3 \%$ using LFIA, following the daily ingestion of a significant amount of gluten $(2 \mathrm{~g})$; rates could be as high as $89.4 \%$ and $96.6 \%$ with the ELISA test and $71.1 \%$ and $84.5 \%$ with the LFIA test in two and three samples, respectively.

\section{Discussion}

In this article, we describe the dynamics of human fecal GIP excretion in conditions simulating occasional gluten exposure under controlled dietary conditions to study individual variability. This is the first study collecting samples of all the following defecations after gluten intake and controlling
Fig. 10 Gluten immunogenic peptides (GIP) detected in fecal samples by ELISA between 12 and $84 \mathrm{~h}$ after gluten ingestion of $50 \mathrm{mg}$ and $2 \mathrm{~g}$ of gluten

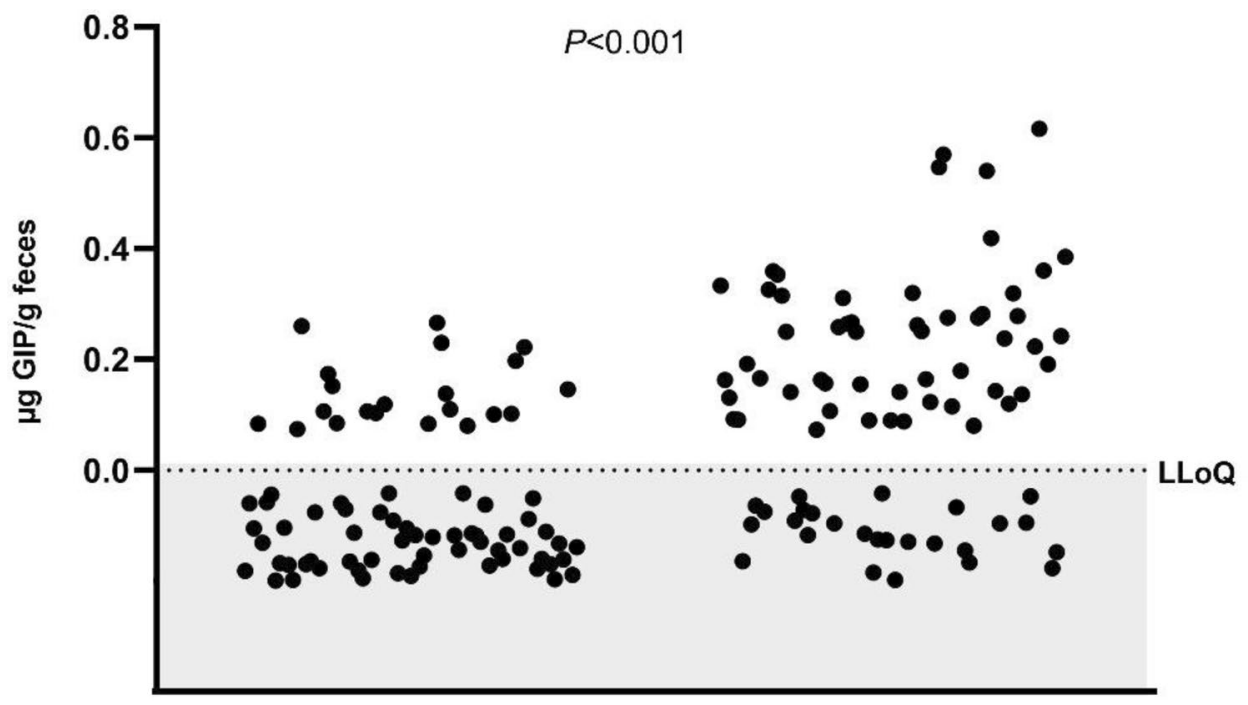

$50 \mathrm{mg}$ $2 \mathrm{~g}$

LLoQ: lower limit of quantification 

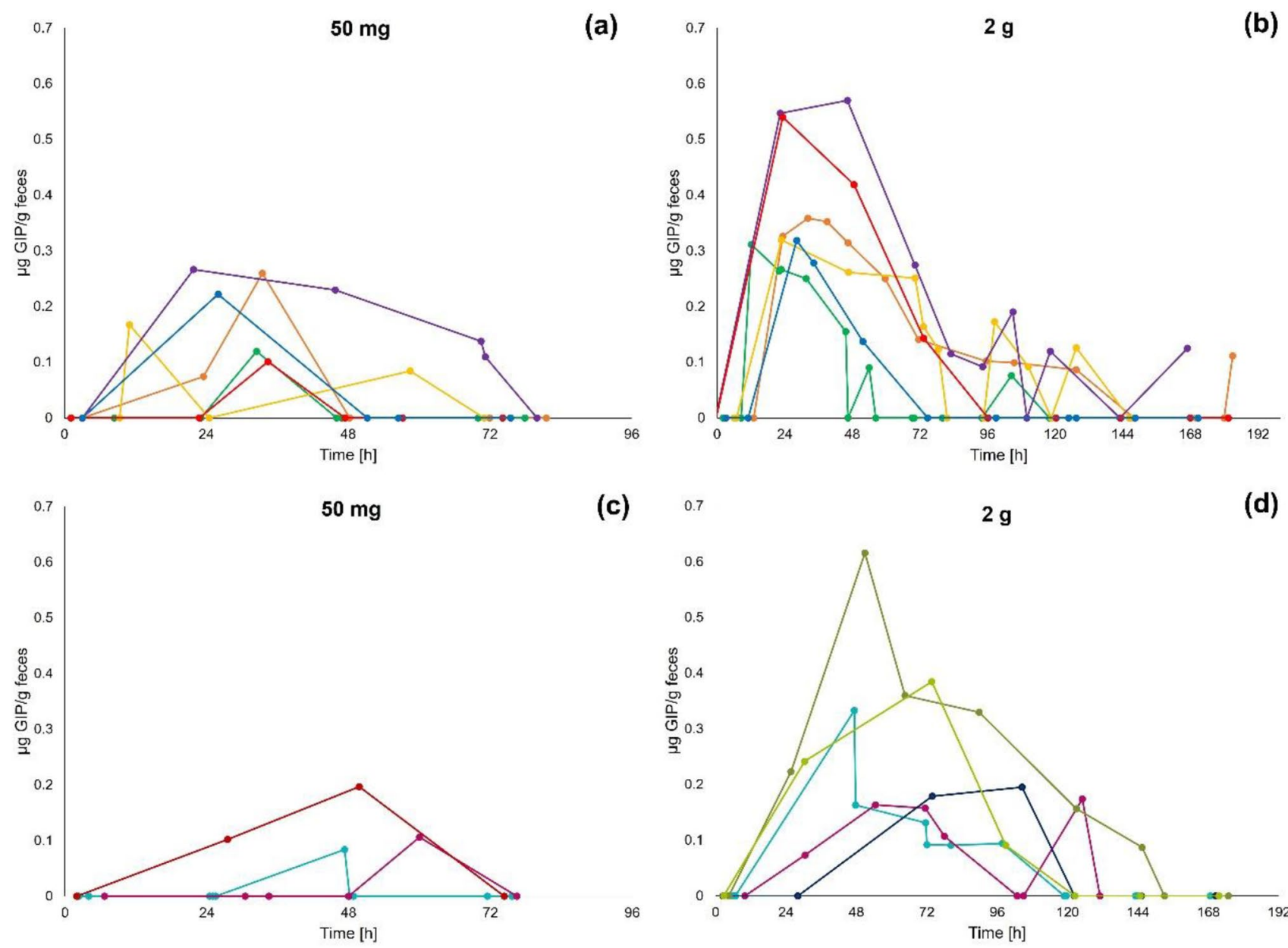

(c)
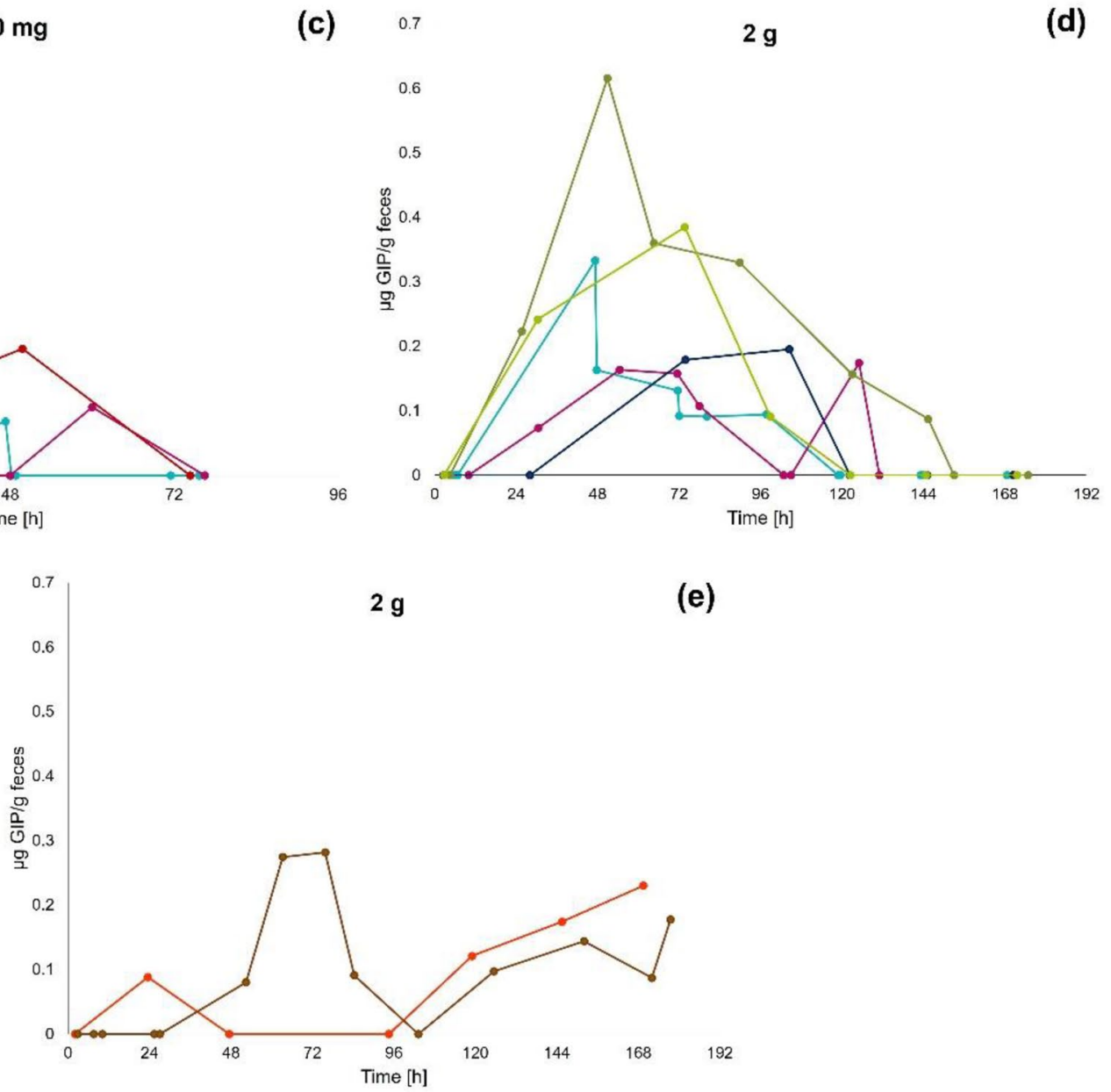

Fig. 11 Individual variations in patterns of fecal gluten immunogenic peptides (GIP) excretion by ELISA. Peak of fecal GIP detection within $48 \mathrm{~h}$ after $50 \mathrm{mg}$ (a) and $2 \mathrm{~g}$ (b) gluten ingestions, peak

diet variables to determine the range of individual variability in the excretion of fecal GIP.

In this study, ingestion of a single dose of $50 \mathrm{mg}$ of gluten was associated with GIP-positive stool over a period of fecal GIP detection from $48 \mathrm{~h}$ after $50 \mathrm{mg}$ (c) and $2 \mathrm{~g}$ (d) gluten ingestions and increasing fecal GIP detection from 5 days after $2 \mathrm{~g}$ gluten ingestion (e)

of $11-72 \mathrm{~h}$ in healthy subjects with a median time of $27 \mathrm{~h}$ required for the initial detection and a peak of detection from 12 to $60 \mathrm{~h}$, with most GIP excreted in only a single sample per participant. Moreover, ingestion of a 40 -fold higher dose 
Table 4 Comparison of diagnostic sensitivity of the ELISA and lateral flow immunoassay within a specific time range and across different samples

\begin{tabular}{|c|c|c|c|c|c|c|c|c|c|c|c|c|c|}
\hline & \multicolumn{13}{|l|}{ Sensitivity } \\
\hline & \multirow[b]{2}{*}{ Time $[\mathrm{h}]$} & \multicolumn{4}{|c|}{1 sample } & \multicolumn{4}{|c|}{2 samples } & \multicolumn{4}{|c|}{3 samples } \\
\hline & & $12-84$ & $12-36$ & $36-60$ & $\overline{60-84}$ & $12-84$ & $12-36$ & $36-60$ & $\overline{60-84}$ & $12-84$ & $12-36$ & $36-60$ & $\overline{60-84}$ \\
\hline \multirow[t]{2}{*}{$50 \mathrm{mg}$ gluten } & LFIA [\%] & 10.4 & 14.8 & 12.5 & 3.9 & 19.7 & 27.4 & 23.4 & 7.5 & 28.0 & 38.2 & 33 & 11.1 \\
\hline & ELISA [\%] & 27.3 & 40.7 & 25 & 15.4 & 47.1 & 64.9 & 43.8 & 28.4 & 61.5 & 79.2 & 57.8 & 39.4 \\
\hline \multirow[t]{2}{*}{2 g gluten } & LFIA [\%] & 46.3 & 59.3 & 54.2 & 27.6 & 71.1 & 83.4 & 79 & 47.6 & 84.5 & 93.2 & 90.4 & 62 \\
\hline & ELISA [\%] & 67.5 & 66.7 & 66.7 & 69 & 89.4 & 88.9 & 88.9 & 90.4 & 96.6 & 96.3 & 96.3 & 97 \\
\hline
\end{tabular}

Interval of time convenient for GIP detection is in bolditalics

LFIA lateral flow immunoassay, ELISA enzyme-like immunosorbent assay

of gluten $(2 \mathrm{~g})$, was associated with similar results regarding the time interval after which most samples showed GIPpositive results (12-84 h), and no statistically significant differences were observed regarding the initial time of GIP detection ( $27 \mathrm{~h}$ vs. $28 \mathrm{~h}, P=0.239$ ). However, the time range for GIP detection significantly differed depending upon the amounts of gluten ingested. GIP remained in the gastrointestinal tract of participants for a median time of $72 \mathrm{~h}$; however, the duration of GIP detection was as long as 7 days in a few individuals. It is possible that undetectable GIP could also get eliminated during that period after ingestion of $50 \mathrm{mg}$ of gluten in some participants, but the amount of GIP may not reach the threshold level considering the sensitivity of methods used in the study.

Our results agreed to those reported by other studies. Comino et al. [17] first reported that the ELISA method based on anti-33mer monoclonal antibodies could detect gluten-derived peptides in the feces of patients with $C D$ and healthy volunteers, following ingestion of processed bread containing between $50 \mathrm{mg}$ and $30 \mathrm{~g}$ of gluten. These authors observed that the time required for gluten-derived peptide excretion was from 2-4 days in six volunteers. Silvester et al. observed similar findings in patients with $C D$ in whom they confirmed an association between definite gluten exposure and GIP positivity in stools $2-4$ days after gluten ingestion [32]. However, it was not fully feasible to accurately establish the expected period of detection owing to the high interindividual variability observed in these studies. Our results obtained in a larger number of participants $(n=20)$ showed GIP detection between the 2 nd and 7 th days of a gluten challenge.

A study performed in a small group of healthy participants observed the kinetics of fecal GIP elimination over a week after the start of a GFD, and the authors found high interindividual variability; detection of GIP occurred over $>3$ days in some and even until the end of the week in other participants [30]. Although the specific moment and quantity of gluten ingestion were not reported, the results of our study were consistent with those of the aforementioned study with regard to the diversity in GIP elimination patterns. In fact, all the examples described in this publication were represented by the participants in our study: however, our results revealed that the individual GIP excretion pattern may be independent of the amount of gluten ingested, considering the initial time of detection and peak of maximum excreted GIP. The amount of GIP is expected to decrease over time for a single gluten dose; however, interestingly, in both studies, we observed intermittent GIP-positive and GIP-negative samples. Furthermore, in two participants a significantly higher fecal GIP content was observed after several days without any fecal GIP detection. The eventual ingestion of gluten was unlikely because parallel urine test controls were negative. These findings may be attributable to the discrete gluten particles that could remain temporarily encapsulated by food matrixes or occasionally retained in the intestine. Although this phenomenon only occurred after the ingestion of $2 \mathrm{~g}$ of gluten, it cannot be ruled out that this pattern was also present in the $50 \mathrm{mg}$ dose, but perhaps GIP were undetectable because the amount of gluten was 40-fold lower.

Roca et al. [31] investigated the dynamics of GIP clearance in stools over 6 days in 18 recently diagnosed pediatric patients with $\mathrm{CD}$, who were provided a GFD, and observed that GIP decreased over time in a non-linear manner; however, GIP recovery decreased in the first $48 \mathrm{~h}$, with minimal detection in most samples between 48 and $72 \mathrm{~h}$. Considering the clearance time for quantities of gluten ranging from $0.7 \mathrm{~g}$ to $11.6 \mathrm{~g} /$ day used in this study, we observed discrepancies in our results; we could expect at least minimal GIP excretion at $72 \mathrm{~h}$. However, this discordance could be attributed to possible inaccuracies in the food-recall questionnaire used for gluten intake estimation.

With regard to the fecal GIP concentration, previous studies have described a weak association between the amount of gluten ingested and fecal GIP excretion [17, 31, 36, 37]. Our results confirmed this association; we observed significant differences in fecal GIP content between volunteers who were administered $50 \mathrm{mg}$ and $2 \mathrm{~g}$ gluten $(P=0.013)$ with a 
significantly greater variation when results were determined in the $12-84 \mathrm{~h}$ range $(P<0.001)$. However, as expected, we observed high interindividual variability, with median GIP ranging from $0.08 \mu \mathrm{g} / \mathrm{g}-0.22 \mu \mathrm{g} / \mathrm{g}$ for the $50 \mathrm{mg}$ dose and $0.09 \mu \mathrm{g} / \mathrm{g}-0.42 \mu \mathrm{g} / \mathrm{g}$ for the $2 \mathrm{~g}$ dose. The aforementioned studies reported fecal GIP quantities of $0.4 \mu \mathrm{g} \mathrm{GIP} / \mathrm{g}$ feces $-7 \mu \mathrm{g} \mathrm{GIP/g}$ feces with daily gluten ingestion ranging from $50 \mathrm{mg}$ to $1 \mathrm{~g}$ in patients with CD and $0.2 \mu \mathrm{g} \mathrm{GIP/g}$ feces- $29 \mu \mathrm{g}$ GIP/g feces with a normal GCD in healthy subjects [17]. Roca et al. [37] also reported a mean of $13 \mu \mathrm{g}$ GIP/g feces (range $0.56 \mu \mathrm{g} / \mathrm{g}-47 \mu \mathrm{g} / \mathrm{g}$ ) following gluten intake ranging from $0.5 \mathrm{~g} /$ day to $10.5 \mathrm{~g} /$ day. The disparity between our results and those of previous studies could be attributed to the matrix containing gluten used in the study (capsule with partially purified gluten in this study vs. normal food in previous studies), the methodology used for the estimation of gluten ingestion, and the frequency of gluten ingestion.

In this study, we confirmed the sensitivity of the ELISA method for frequent detection of gluten ingestion of $50 \mathrm{mg}$, which concurs with results of a previous study [17]. Although the ELISA method showed higher sensitivity than the LFIA test, both techniques showed concordance. Similar results were reported by other studies [17, 36, 37], in which diagnostic sensitivity of the ELISA method ranged from 98.5 to $100 \%$ with diagnostic specificity of $100 \%$, and the diagnostic sensitivity and specificity of the LFIA method were $75 \%$ and $100 \%$, respectively, showing moderate concordance [17, 37]. False-positive results were discarded in our study because the extended experience in the specificity of the G12 immunomethods either in food or in human samples. According to this assumption, GIP detection was observed after gluten ingestion and subsequently to consecutive GIP-negative samples that confirmed the compliance of the volunteers performing the GFD. Samples from those participants with moderate levels of GIP in feces after the wash-out week were excluded as we could not assure that GIP detection was from the $50 \mathrm{mg}$ gluten dose. Previous studies with volunteers undergoing a GFD showed absence or very low rate of positive excreted GIP [17, 37]. Moreover, we have a rigorous control of the gluten content of the food consumed by the participants (see above in "Materials and methods").

Discordant results could be explained by differences in the configuration of immunomethods (A1/G12 antibodies for the LFIA test and G12/G12 for the ELISA test) and the different efficiency of GIP extraction methods. Usually, samples with GIP-negative result on ELISA testing also show negative results with the LFIA test; but some samples that show a GIP-positive result by ELISA could have a low GIP content that is below to the limit of detection of the LFIA test [22, 31, 37]. However, some discrepancies may occur; for example, we observed six GIP-positive results using
LFIA, although these samples tested negative using ELISA testing. This difference may be associated with the heterogeneous distribution of GIP in feces, or the antibody pair used in each method, which may show differing affinity for some peptides, as mentioned earlier. The large heterogeneity of feces composition, even in the same sample of the same individual was already described by other authors [38-40]. In this study, we aimed to reduce such heterogeneity by the homogenization of each fecal sample prior to analysis and by the determination of GIP from different aliquots taken from the same sample from each participant with each method. Nonetheless, as LFIA and ELISA tests have different extraction protocols for feces samples, each aliquot was analyzed independently with both tests.

Our results can serve to design the recommendations for the sampling of the immunotechniques to increase the sensitivity and estimate the source of GFD transgressions. Reportedly, patients with CD tend to show frequent dietary transgressions despite efforts to strictly follow a GFD [17, 22, 24, 32]; however, inadvertent gluten intake is difficult to determine. Gluten intake in individuals who are prescribed a GFD, could be secondary to regular dietary non-compliance or inadvertent transgressions. Detection of fecal GIP could likely indicate gluten intake in the preceding $12-72 \mathrm{~h}$. An increase in the frequency of stool tests appears to be a convenient approach to avoid false-negative results in those showing non-compliance with GFD resultant from occasional gluten intake [22, 31]. Stefanolo et al. [22] reported that $62 \%$ of patients showed at least one GIP-positive result in weekly stool samples obtained over a month, with a median of three positive results during this period. Considering that minimal daily gluten ingestion $(50 \mathrm{mg})$ can cause mucosal injury in most patients with $\mathrm{CD}$ and being it useful to adopt a more realistic approach with regard to a GFD, it may be convenient the use of several fecal GIP tests for a week and separated 3-4 days to include weekdays and weekends (for example, Tuesday/Wednesday and Friday/Saturday). The increase of frequency of stool sample collection could solve any clinical need to improve sensitivity of the method for detection of lowsingle gluten intakes. For instance, the collection of three stool samples to cover gluten exposure on both weekdays and weekends may increase the diagnostic sensitivity of the ELISA to $61.5 \%$ for $50 \mathrm{mg}$ of gluten intake and $96.6 \%$ for $2 \mathrm{~g}$ gluten ingestion.

Overall, our study highlighted high interindividual variability in excretion time and GIP concentrations, which concurs with the results of previous research in this domain. The heterogeneity observed could be attributed to multiple contributors including gastrointestinal transit time, intestinal permeability, hydrolytic capacity of human enzymes, and intestinal microbiota activity. 
Several studies have reported that both patients with CD and healthy subjects have gluten-degrading bacteria that can hydrolyze immunogenic peptides and fecal glutenasic activity in individuals is inversely associated with the amount of gluten excreted [15-17, 41, 42]. These factors may explain the negative results in all the stool samples collected after $50 \mathrm{mg}$ and $2 \mathrm{~g}$ gluten ingestions despite positive results for urinary GIP after the second dose in one participant in this study [33]. However, the possibility of a missing sample in this participant might not be discarded. In our study, we controlled the gluten dosage and dietary composition to minimize the variables analyzed. The significant differences among participants highlight the realistic scenario that should be considered when establishing protocols for stool collection for GFD monitoring.

In the present study, the variability found between participants in the detection of GIP in urine [33] and feces makes difficult to establish a general pattern between the individual excretion of GIP in both types of samples. Apparently, some of the factors previously mentioned might affect GIP excretion in urine and feces in like manner, but we observed that elements such as fluid intake may significantly modify the sensitivity of the GIP test in urine samples [33], independently of the individual. Despite the lack of strict associations between both type of samples, it was possible to observe detectable amounts of GIP in almost all individuals after the two gluten intakes in either urine or feces (only 4 participants have negative results in both samples after the $50 \mathrm{mg}$ dosage). Besides, we perceived some coincidences in the detection of GIP in urine and feces in several participants. For instance, considering the initial time of GIP detection after $2 \mathrm{~g}$ gluten intake, 4 participants were the first ones to excrete detectable amounts of GIP in urine (3-5 h) and feces $(22-25 \mathrm{~h})$, and 2 participants had a delayed detection of GIP ( $8 \mathrm{~h}$ and 51-52 h, respectively). In addition, 3 participants showed low median concentrations of GIP in both types of samples after the $2 \mathrm{~g}$ ingestion and, on the contrary, the urine and feces samples from one participant were within the highest GIP concentration medians.

Immunoassays for fecal GIP detection are useful in patients diagnosed with $\mathrm{CD}$ and gluten-related disorders. A limitation of this study was that only healthy volunteers were included, which was mainly due to ethical issues. There is no sufficient evidences that the metabolism of gluten proteins is different between patients with $\mathrm{CD}$ and healthy individuals; however, previous research has reported that patients with $\mathrm{CD}$ could show digestive abnormalities in the digestion process [43]. It has also been reported that intestinal microbiota involved in gluten metabolism could be altered in patients with CD [41]. Future studies in these patient populations may confirm the equivalences and any potential deviations in the dynamics of gluten excretion compared to healthy population. Keeping in mind this concern, this report may be valuable to define the protocols for the application of fecal GIP estimation to assess gluten exposure during follow-up of gluten-induced disorders in real-world clinical practice.

Acknowledgements This paper will be part of the Laura Coto's doctorate that it is being carried out within the context of "Human Nutrition Program" at the University of Granada. She was supported by a Research Fellowship from the Government of Spain (DI-16-08943). We also thank the generous volunteer subjects who enrolled in the study.

Author contributions All authors contributed to the study conception and design. Material preparation, data collection and analysis were performed by LC. The first draft of the manuscript was written by LC and all authors commented on previous versions of the manuscript. All authors read and approved the final manuscript.

Funding This work was supported by grants from Ministerio de Ciencia e Innovación (DI-16-08943), Junta de Andalucía, Consejería de Economía, Conocimiento, Empresas y Universidad and FEDER funds (AT17_5489_USE), Centro para el Desarrollo Tecnológico Industrial (IDI-20180051) and Corporación Tecnológica de Andalucía (17/957).

\section{Declarations}

Conflict of interest Angel Cebolla is the founder and current CEO of Biomedal S.L. (Seville, Spain), Angel Cebolla and Carolina Sousa are inventors of the patent "Detecting gluten peptides in human fluids" (no. WO/2016/005643), and Laura Coto is employee at Biomedal S.L.

Availability of data and material Not registered.

Code availability Not applicable.

Ethics approval The study was conducted according to the guidelines of the Declaration of Helsinki, and approved by the Ethics Committee of Virgen del Rocío and Virgen Macarena University Hospitals (n. 2381-N-19; 03/02/2020).

Consent to participate Informed consent was obtained from all individual participants included in the study.

Consent for publication Not applicable.

Open Access This article is licensed under a Creative Commons Attribution 4.0 International License, which permits use, sharing, adaptation, distribution and reproduction in any medium or format, as long as you give appropriate credit to the original author(s) and the source, provide a link to the Creative Commons licence, and indicate if changes were made. The images or other third party material in this article are included in the article's Creative Commons licence, unless indicated otherwise in a credit line to the material. If material is not included in the article's Creative Commons licence and your intended use is not permitted by statutory regulation or exceeds the permitted use, you will need to obtain permission directly from the copyright holder. To view a copy of this licence, visit http://creativecommons.org/licenses/by/4.0/. 


\section{References}

1. Caio G, Volta U, Sapone A, Leffler DA, De Giorgio R, Catassi C, Fasano A (2019) Celiac disease: a comprehensive current review. BMC Med 17(1):142. https://doi.org/10.1186/s12916-019-1380-Z

2. Jabri B, Sollid LM (2006) Mechanisms of disease: immunopathogenesis of celiac disease. Nat Clin Pract Gastroenterol Hepatol 3(9):516-525. https://doi.org/10.1038/ncpgasthep0582

3. Lindfors K, Ciacci C, Kurppa K, Lundin KEA, Makharia GK, Mearin ML, Murray JA, Verdu EF, Kauniken K (2019) Coeliac disease. Nat Rev Dis Prim 5(1):3. https://doi.org/10.1038/ s41572-018-0054-z

4. Sollid LM (2002) Coeliac disease: dissecting a complex inflammatory disorder. Nat Rev Immunol 2(9):647-655. https://doi.org/ 10.1038/nri885

5. Abadie V, Sollid LM, Barreiro LB, Jabri B (2011) Integration of genetic and immunological insights into a model of celiac disease pathogenesis. Annu Rev Immunol 29:493-525. https://doi.org/10. 1146/annurev-immunol-040210-092915

6. Loeff T, Araya M, Pérez-Bravo F (2012) Frequency of MYO9B polymorphisms in celiac patients and controls. Rev Esp Enferm Dig 104(11):566-571. https://doi.org/10.4321/s1130-01082012001100003

7. Wapenaar MC, Monsuur AJ, van Bodegraven AA, Weersma RK, Bevova MR, Linskens RK, Howdle P, Holmes G, Mulder CJ, Dijkstra G, van Heel DA, Wijmenga C (2008) Associations with tight junction genes PARD3 and MAGI2 in Dutch patients point to a common barrier defect for coeliac disease and ulcerative colitis. Gut 57(4):463-467. https://doi.org/10.1136/gut.2007.133132

8. Shan L, Molberg O, Parrot I, Hausch F, Filiz F, Gray GM, Sollid LM, Khosla C (2002) Structural basis for gluten intolerance in celiac sprue. Science 297(5590):2275-2279. https://doi.org/10. 1126/science. 1074129

9. Tye-Din JA, Stewart JA, Dromey JA, Beissbarth T, van Heel DA, Tatham A, Henderson K, Mannering SI, Gianfrani C, Jewell DP, Hill AVS, McCluskey J, Rossjohn J, Anderson RP (2010) Comprehensive, quantitative mapping of $\mathrm{T}$ cell epitopes in gluten in celiac disease. Sci Transl Med 2(41):41-51. https://doi.org/10. 1126/scitranslmed.3001012

10. Mena MC, Sousa C (2015) Analytical tools for gluten detection. Policies and regulation. In: Advances in the understanding of gluten related pathology and the evolution of gluten-free foods. OmniaScience pp 527-64. http://www.omniascience.com/monog raphs/index.php/monograficos/article/view/264

11. Shewry PR, Halford NG, Belton PS, Tatham AS (2002) The structure and properties of gluten: an elastic protein from wheat grain. Philos Trans R Soc B Biol Sci 357(1418):133-142. https://doi. org/10.1098/rstb.2001.1024

12. Bhutia YD, Ganapathy V (2018) Protein digestion and absorption. Physiology of the gastrointestinal tract. Elsevier, Amsterdam, pp 1063-1086

13. Caminero A, Nistal E, Herrán AR, Pérez-Andrés J, Vaquero L, Vivas S, Ruiz de Morales JM, Casqueiro J (2014) Gluten metabolism in humans. Wheat and rice in disease prevention and health. Elsevier, Amsterdam, pp 157-170

14. Moreno ML, Cebolla Á, Muñoz-Suano A, Carrillo-Carrion C, Comino I, Pizarro Á, León F, Rodríguez-Herrera A, Sousa C (2017) Detection of gluten immunogenic peptides in the urine of patients with coeliac disease reveals transgressions in the glutenfree diet and incomplete mucosal healing. Gut 66(2):250-257. https://doi.org/10.1136/gutjnl-2015-310148

15. Herrán AR, Pérez-Andrés J, Caminero A, Nistal E, Vivas S, Ruiz de Morales JM, Casqueiro J (2017) Gluten-degrading bacteria are present in the human small intestine of healthy volunteers and celiac patients. Res Microbiol 168(7):673-684. https://doi.org/10. 1016/j.resmic.2017.04.008
16. Caminero A, Nistal E, Arias L, Vivas S, Comino I, Real A, Sousa C, Ruiz de Morales JM, Ferrero MA, Rodríguez-Aparicio LB, Casqueiro J (2012) A gluten metabolism study in healthy individuals shows the presence of faecal glutenasic activity. Eur J Nutr 51(3):293-299. https://doi.org/10.1007/s00394-011-0214-3

17. Comino I, Real A, Vivas S, Síglez MÁ, Caminero A, Nistal E et al (2012) Monitoring of gluten-free diet compliance in celiac patients by assessment of gliadin 33-mer equivalent epitopes in feces. Am J Clin Nutr. 95(3):670-677. https://doi.org/10.3945/ ajen.111.026708

18. Ludvigsson JF, Leffler DA, Bai JC, Biagi F, Fasano A, Green PHR, Hadjivassiliou M, Kauniken K, Kelly CP, Leonard JN, Lundin KEA, Murray JA, Sanders DS, Walker MM, Zingone F, Ciacci C (2013) The Oslo definitions for coeliac disease and related terms. Gut 62(1):43-52. https://doi.org/10.1136/gutjnl-2011-301346

19. Troncone R, Auricchio R, Granata V (2008) Issues related to gluten-free diet in coeliac disease. Curr Opin Clin Nutr Metab Care 11(3):329-333. https://doi.org/10.1097/MCO.0b013e3282 f795f8

20. Hall NJ, Rubin G, Charnock A (2009) Systematic review: adherence to a gluten-free diet in adult patients with coeliac disease. Aliment Pharmacol Ther 30(4):315-330. https://doi.org/10. 1111/j.1365-2036.2009.04053.x

21. Villafuerte-Galvez J, Vanga RR, Dennis M, Hansen J, Leffler DA, Mukherjee KCP (2015) Factors governing long-term adherence to a gluten-free diet in adult patients with coeliac disease. Aliment Pharmacol Ther 42(6):753-760. https://doi.org/10.1111/apt.13319

22. Stefanolo JP, Tálamo M, Dodds S, de la Paz TM, Costa AF, Moreno ML, Pinto-Sánchez MI, Smecuol E, Vázquez H, Gonzalez A, Niveloni SI, Mauriño E, Verdu EF, Bai JC (2021) Real-world gluten exposure in patients with celiac disease on gluten-free diets, determined from gliadin immunogenic peptides in urine and fecal samples. Clin Gastroenterol Hepatol 19(3):484-491.e1. https://doi.org/10.1016/j.cgh.2020.03.038

23. Ruiz-Carnicer Á, Garzón-Benavides M, Fombuena B, Segura V, García-Fernández F, Sobrino-Rodríguez S, Gómez-Izquierdo L, Montes-Cano MA, Rodríguez-Herrera A, Millán R, Rico MC, González-Naranjo C, Bozada-García JM, Díaz J, CoronelRodríguez C, Espín B, Romero-Gómez M, Cebolla Á, Sousa C, Comino I, Argüelles F, Pizarro Á (2019) Negative predictive value of the repeated absence of gluten immunogenic peptides in the urine of treated celiac patients in predicting mucosal healing: new proposals for follow-up in celiac disease. Am J Clin Nutr 112(5):1240-1251. https://doi.org/10.1093/ajcn/nqaa188

24. Muhammad H, Reeves S, Jeanes YM (2019) Identifying and improving adherence to the gluten-free diet in people with coeliac disease. Proc Nutr Soc 78(3):418-425. https://doi.org/10.1017/ S002966511800277X

25. Myléus A, Reilly NR, Green PHR (2020) Rate, risk factors, and outcomes of nonadherence in pediatric patients with celiac disease: a systematic review. Clin Gastroenterol Hepatol 18(3):562573. https://doi.org/10.1016/j.cgh.2019.05.046

26. Itzlinger A, Branchi F, Elli L, Schumann M (2018) Gluten-free diet in celiac disease-forever and for all? Nutrients 10(11):1796. https://doi.org/10.3390/nu10111796

27. Catassi C, Fabiani E, Iacono G, D’Agate C, Francavilla R, Biagi F, Volta U, Accomando S, Picarelli A, De Vitis I, Pianelli G, Gesuita R, Carle F, Mandolesi A, Bearzi I, Fasano A (2007) A prospective, double-blind, placebo-controlled trial to establish a safe gluten threshold for patients with celiac disease. Am J Clin Nutr 85(1):160-166. https://doi.org/10.1093/ajcn/85.1.160

28. Collin P, Thorell L, Kaukinen K, Mäki M (2004) The safe threshold for gluten contamination in gluten-free products. Can trace amounts be accepted in the treatment of coeliac disease? Aliment Pharmacol Ther 19(12):1277-1283. https://doi.org/10.1111/j. 1365-2036.2004.01961.x 
29. Comino I, Fernández-Bañares F, Esteve M, Ortigosa L, Castillejo G, Fambuena B, Ribes-Koninckx C, Sierra C, Rodríguez-Herrera A, Salazar JC, Caunedo Á, Marugán-Miguelsanz JM, Garrote JA, Vivas S, Lo Iacono O, Nuñez A, Vaquero L, Vegas AM, Crespo L, Fernández-Salazar L, Arranz E, Jiménez-García VA, Antonio Montes-Cano M, Espín B, Galera A, Valverde J, Girón FJ, Bolonio M, Millán A, Cerezo FM, Guajardo C, Alberto JR, Rosinach M, Segura V, León F, Marinich J, Muñoz-Suano A, Romero-Gómez M, Cebolla Á, Sousa C (2016) Fecal gluten peptides reveal limitations of serological tests and food questionnaires for monitoring gluten-free diet in celiac disease patients. Am J Gastroenterol 111(10):1456-1465. https://doi.org/10.1038/ajg.2016.439

30. Gatti S, Guazzarotti A, Quattrini S, Galeazzi T, Catassi C (2015) Detection of gluten immunogenic peptides (GIP) in stools as a method of monitoring the gluten-free diet in children. In: Proceedings of the 28 th Meeting WORKING GROUP on PROLAMIN ANALYSIS and TOXICITY, Chemistry, German Research Centre for Food Freising; pp 113-8. Available from: http://www.dd2u. brussels/Files/Other/Gatti-Catassi-Detection-of-Gluten-Immun ogenic-Peptides-(GIP)-in-stool.pdf

31. Roca M, Donat E, Masip E, Crespo-Escobar P, Cañada-Martínez AJ, Polo B, Ribes-koninckx C (2020) Analysis of gluten immunogenic peptides in feces to assess adherence to the gluten-free diet in pediatric celiac patients. Eur J Nutr 60(4):2131-2140. https:// doi.org/10.1007/s00394-020-02404-Z

32. Silvester JA, Comino I, Rigaux LN, Segura V, Green KH, Cebolla A, Weiten D, Dominguez R, Leffler DA, Leon F, Bernstein CN, Graff LA, Kelly CP, Sousa C, Duerksen DR (2020) Exposure sources, amounts and time course of gluten ingestion and excretion in patients with coeliac disease on a gluten-free diet. Aliment Pharmacol Ther 52(9):1469-1479. https://doi.org/10.1111/apt. 16075

33. Coto L, Sousa C, Cebolla A (2021) Dynamics and considerations in the determination of the excretion of gluten immunogenic peptides in urine: individual variability at low gluten intake. Nutrients 13(8):2624. https://doi.org/10.3390/nu13082624

34. Biagi F, Andrealli A, Bianchi PI, Marchese A, Klersy C, Corazza GR (2009) A gluten-free diet score to evaluate dietary compliance in patients with coeliac disease. Br J Nutr 102(6):882-887. https:// doi.org/10.1017/S0007114509301579

35. Landis JR, Koch GG (1977) The measurement of observer agreement for categorical data. Biometrics 33(1):159-174

36. Costa AF, Sugai E, Temprano MP, Niveloni SI, Vázquez H, Moreno ML, Domínguez-Flores MR, Muñoz-Suano A, Smecuol
E, Stefanolo JP, González AF, Cebolla-Ramirez A, Mauriño E, Verdú EF, Bai JC (2019) Gluten immunogenic peptide excretion detects dietary transgressions in treated celiac disease patients. World J Gastroenterol 25(11):1409-1420. https://doi.org/10.3748/ wjg.v25.i11.1409

37. Roca M, Donat E, Masip E, Crespo Escobar P, Fornes-Ferrer V, Polo B, Ribes-Koninckx C (2019) Detection and quantification of gluten immunogenic peptides in feces of infants and their relationship with diet. Rev Esp Enferm Dig 111(2):106-110. https://doi. org/10.17235/reed.2018.5549/2018

38. Zreloff ZJ, Lange D, Vernon SD, Carlin MR, Cano RDJ (2021) Accelerating gut microbiome research with robust sample collection. Preprints 2021:2021010047. https://doi.org/10.20944/prepr ints202101.0047.v1

39. Deutsch L, Stres B (2021) The importance of objective stool classification in fecal 1H-NMR metabolomics: exponential increase in stool crosslinking is mirrored in systemic inflammation and associated to fecal acetate and methionine. Metabolites 11(3):1-16. https://doi.org/10.3390/metabo11030172

40. Erben V, Poschet G, Schrotz-King P, Brenner H (2021) Evaluation of different stool extraction methods for metabolomics measurements in human faecal samples. BMJ Nutr Prev Health. https:// doi.org/10.1136/bmjnph-2020-000202

41. Caminero A, Nistal E, Herrán AR, Pérez-Andrés J, Ferrero MA, Vaquero Ayala L, Vivas S, Ruiz de Morales JM, Albillos SM, Casqueiro FJ (2015) Differences in gluten metabolism among healthy volunteers, coeliac disease patients and first-degree relatives. Br J Nutr 114(8):1157-1167. https://doi.org/10.1017/S0007 114515002767

42. Caminero A, Galipeau HJ, McCarville JL, Johnston CW, Bernier SP, Russell AK, Jury J, Herran AR, Casqueiro J, Tye-Din JA, Surette MG, Magarvey NA, Schuppan D, Verdu EF (2016) Duodenal bacteria from patients with celiac disease and healthy subjects distinctly affect gluten breakdown and immunogenicity. Gastroenterology 151(4):670-683. https://doi.org/10.1053/j.gastro.2016.06.041

43. Caminero A, Herrán AR, Nistal E, Pérez-Andrés J, Vaquero L, Vivas S, Ruiz de Morales JM, Albillos SM, Casqueiro J (2014) Diversity of the cultivable human gut microbiome involved in gluten metabolism: Isolation of microorganisms with potential interest for coeliac disease. FEMS Microbiol Ecol 88(2):309-319. https://doi.org/10.1111/1574-6941.12295 